\title{
Resolving Conflicts Between Endangered Species Conservation and Renewable Energy Siting: Wiggle Room for Renewables?
}

\author{
Gregg Badichek \\ Juris Doctor Candidate, 2016 \\ Columbia Law School, New York \\ gmb2149@,columbia.edu
}

\begin{abstract}
Two federal policies - the protection of endangered species, and the rapid creation of renewable energy infrastructure-currently exist in significant legal tension. While both are important for the development of necessary sustainability, climate change induced by the continuous burning of carbon-based fuels likely poses a greater threat to endangered species than does the growth of commercialscale renewable energy sites. This paper outlines several points of conflict between the two policies and subsequently considers the extent to which federal agencies responsible for renewable energy oversight and development possess "wiggle room" under the Endangered Species Act. A few recommendations for greater leeway are then offered.
\end{abstract}

\section{Author's Note}

The author would like to thank Professor Michael Gerrard of Columbia Law School for providing intellectual resources and constant mentorship, as well as Ashleigh PP Hunt for invaluable editing, inspiration, and support.

Keywords: Endangered Species Act, Energy Policy Act, renewable energy infrastructure, endangered species, Indiana Bat, climate change.

\section{Introduction}

It is widely accepted that the United States' energy infrastructure must undergo a dramatic restructuring away from traditional fossil fuel energy sources, and toward low-carbon renewable energy sources, if the most catastrophic effects of anthropogenic climate change are to be avoided in the long term. ${ }^{1}$

1 The Intergovernmental Panel on Climate Change (IPCC) has long held that global warming must not exceed $2^{\circ} \mathrm{C}$ from preindustrial levels to stave off catastrophic climate change. See Climate Change 2014: Mitigation of Climate Change, INTERGOVERnMENTAL PANEL ON Climate CHAnge (2014), available at http://www.ipcc.ch/report/ar5/wg3/. Nations pledged to work toward this goal at the 2009 United Nations Framework on Climate Change Summit in Copenhagen. See Rep. of the Conference of the Parties on its Fifteenth Session, U.N.F.C.C. (Dec. 2009), available at http://maindb.unfccc.int/library/view_pdf.pl?url=http://unfccc.int/resource/docs/2009/c op15/eng/11a01.pdf. An $80 \%$ reduction in greenhouse gas pollution by 2050 is generally agreed upon by scientists as the target necessary to reduce significant impacts from climate 
Surprisingly, the U.S. Congress has not been wholly inactive in pursuing this goal, even though the federal and state governments have made considerable progress in revamping the nation's energy infrastructure. ${ }^{2}$ However, due to the considerable ecological disturbances that accompany large-scale infrastructural change generally and renewable energy development specifically, this vital policy runs up against another, older Congressionally endorsed effort: the protection of threatened and endangered wildlife species.

This paper presumes that it is preferable to risk the individual lives and, if necessary, existence of some species in pursuit of rapid renewable energy infrastructure development. The alternative-prioritization of species' survival over energy reformatting, resulting in inaction-would increase global climate risk, and ultimately threaten more species and habitats in the long term. The relevant question is: what "wiggle room" do federal agencies, both administering the Endangered Species Act (ESA) and subject to its provisions, have that allows them to facilitate the development of a renewable energy infrastructure while complying with the act?

Part II of this paper provides a background of the two policies, and contextualizes the conflict between them. Part III provides technical details of major renewable energy sources and technologies, and specific ways in which they harm wildlife. Part IV transitions to the legal framework that underlies the conflict. Part V presents "wiggle room" in the statutory framework that would facilitate the speedier development of renewable energy infrastructure. Part VI offers potential solutions and statutory innovations that would further expedite renewable energy development.

\section{Dueling Policies}

Integral to this paper's inquiry is an examination of laws and actions supporting the two environmental policies, endorsed by Congress, that ultimately clash-endangered and threatened species protection, and the rapid development of a national renewable energy infrastructure-and the reasons that they were not designed to complement one another.

\subsection{Endangered and Threatened Species Protection}

Over a century of jurisprudential developments constitute the corpus of federal laws protecting wildlife. Congress has protected wildlife by statute since the passage of the Lacey Act in 1900. ${ }^{3}$ This act makes it unlawful to import, export, sell, acquire, or purchase fish, wildlife, or plants that are taken, possessed, transported, or sold: 1) in violation of U.S. or Indian law, or 2) in interstate or foreign commerce

change; approaching this target would require a deep restructuring of the fossil fuel economy. See U.S. Can Cut Greenhouse Gas Emissions 80 Percent By 2050, Study Says, YALE

ENVIRONMENT 360 (Nov. 21, 2014),

http://e360.yale.edu/digest/us_can_cut_greenhouse_gas_emissions_80_percent_by_2050_s tudy_says/4305.

2 See infra Part II.B.

3 See Lacey Act, U.S. FisH AND WILDLIFE SERVICE, http://www.fws.gov/international/lawstreaties-agreements/us-conservation-laws/lacey-act.html (last accessed Apr. 28, 2015). 
involving any fish, wildlife, or plants taken, possessed, or sold in violation of State or foreign law. ${ }^{4}$ Illegal trade of animals and plants results in civil and criminal penalties and permit sanctions. ${ }^{5}$

Subsequently, and throughout the 20th century, Congress passed numerous statutes that protect particular species and groups of species. ${ }^{6} 1972$ saw the notable passage of the Marine Mammal Protection Act (MMPA), which prohibits the taking of marine mammals in U.S. waters and by U.S. citizens on the high seas, and the importation of marine mammals and their products into the U.S. ${ }^{7}$ In contrast to earlier, pointed conservation laws, the MMPA was the first legislation promoting an ecosystem approach to natural resource management and conservation. ${ }^{8}$ This approach thoroughly permeated the conceptual underpinning of the subsequent ESA.

The presence of a considerable body of wildlife legislation ultimately permitted the employment of statutory focus on demographic conceptions of species, namely endangered and threatened species. This came to the fore with the passage of the seminal Endangered Species Act of 1973, which, as the predominant conservation law dealing with threatened and endangered species, is the most important legislation to the conflict described in this paper. Built upon the basic framework of the earlier, insufficient Endangered Species Preservation Act of 1966, the new law reflected the "policy of Congress that all Federal departments and agencies shall seek to conserve endangered species and threatened species," was enacted "to provide a means whereby the ecosystems upon which endangered" species and threatened ${ }^{12}$ species depend may be conserved." 13 The ESA empowers the Departments of the Interior and Commerce, through the Fish and Wildlife Service (FWS) and the National Marine Fisheries Service (NMFS) (collectively "Service(s)"), respectively, to take legal measures to protect these wildlife and their habitats. ${ }^{14}$

416 U.S.C.A. \3372 (2014).

${ }^{5} I d . \$ 3373$.

6 See, e.g., the Bald and Golden Eagle Protection Act, 16 U.S.C. SS 668-668d, passed in 1940, which prohibits "taking" bald eagles without a permit.

716 U.S.C.A. 1631-1407 (2014).

8 See Marine Mammals, U.S. FiSH AND WiLDlifE SERVICE, http://www.fws.gov/habitatconservation/marine_mammals.html (last updated Sep. 22, 2014).

9 See Endangered Species Act, U.S. FISH AND WILDLIFE SERVICE, http://www.fws.gov/endangered/laws-policies/esa-history.html (last updated Jul. 15, 2013).

1016 U.S.C.A. \1531(c)(1) (2014).

11 An endangered species is "any species which is in danger of extinction throughout all or a significant portion of its range ..." Id. \1532(6).

$12 \mathrm{~A}$ threatened species is "any species which is likely to become an endangered species within the foreseeable future throughout all or a significant portion of its range. .." Id. S 1532(20).

${ }_{13} \mathrm{Id}$. $\$ 1531(\mathrm{~b})$.

${ }^{14}$ Id. $\$ 1533$. 


\subsection{Renewable Energy Infrastructure}

More recently, Congress has presented a clear policy supporting the widespread development of renewable energy infrastructure. In 2001, President Bush ordered that "[f]or energy-related projects, agencies shall expedite their review of permits or take other actions as necessary to accelerate the completion of such projects" in a safe and environmentally sound manner. ${ }^{15}$ The Energy Policy Act of 2005 (EPA) commanded that the Secretary of the Interior should, by 2015, have approved non-hydropower renewable energy projects located on the public lands totaling at least 10,000 megawatts. ${ }^{16}$ This meant that the Bureau of Land Management (BLM) had to approve leases for that amount of renewable energy development on public land. This goal was met in October 2012 with the Secretary's approval of the Wyoming Wind Project Site. ${ }^{17}$

The American Reinvestment and Recovery Act of 2009 (ARRA), which encapsulated the stimulus package launched in response to the financial crisis of 2008, created numerous subsidies for wind, solar, and geothermal energy development. The act ultimately allowed the Department of Energy (DOE) to invest more than $\$ 31$ billion in clean energy projects across the nation. ${ }^{18}$ The act also provided tax incentives for renewable development, extending the Production Tax Credit for wind energy development through $2012 ;{ }^{20}$ implementing an option to elect a 30\% Investment Tax Credit or cash grant in lieu of the Production Tax Credit; and expanding a federal loan guarantee program managed by the DOE. ${ }^{21}$

Several states have aligned their policies with Congress'. Many have adopted Renewable Portfolio Standards (RPSs), tools mandating that a certain percentage of retail electricity sold in the state must derive from renewable sources such as wind, solar, and biomass. ${ }^{22}$ Most states currently have either mandatory RPS programs or voluntary Renewable Portfolio Goals in place, ${ }^{23}$ with percentage and absolute targets varying considerably among them. ${ }^{24}$

More recently, Congress has presented a clear policy supporting the

15 Exec. Order No. 13,212, 66 Fed. Reg. 28,357 (May 18, 2001).

${ }^{16}$ Energy Policy Act of 2005, 42 U.S.C.A. \$S 15801-16538 (2014).

17 See Press Release, DePARTMENT OF INTERIOR (Oct. 9, 2012),

http://www.doi.gov/news/pressreleases/Salazar-Authorizes-Landmark-Wyoming-Wind-

Project-Site-Reaches-Presidents-Goal-of-Authorizing-10000-Megawatts-of-Renewable-

Energy.cfm. Note, however, that approval of this much energy is very different from actual installation. The latter process is still in early stages of development.

${ }^{18}$ For an infographic of DOE ARRA funded projects, see Recovery Act, DEPARTMENT OF

ENERGY, http://www.energy.gov/recovery-act (last accessed Apr. 8, 2015).

202009 American Recovery and Reinvestment Act, Pub L. No. 111-5, 123 Stat. 115.

212008 Wind Technologies Market Report, U.S. DePARTMENT OF ENERGY $44-45$ (July 2009), available at http://www.nrel.gov/docs/fy09osti/46026.pdf.

22 See Renewable Portfolio Standards, NREL, http://www.nrel.gov/tech_deployment/state_local_governments/basics_portfolio_standar ds.html (last updated Sep. 8, 2014).

23 See Renewable Porffolio Standards, U.S. EPA, http://www.epa.gov/agstar/tools/funding/renewable.html (last accessed Apr. 28, 2015).

${ }^{24}$ California, e.g., is much higher than most RPSs, and mandates 33\% renewable energy sourcing by 2020. CAL. PUB. UTIL. CODE \S 399.11-.20 (West 2015). 
widespread development of renewable energy infrastructure. In 2001, President Bush ordered that "[f]or energy-related projects, agencies shall expedite their review of permits or take other actions as necessary to accelerate the completion of such projects" in a safe and environmentally sound manner. ${ }^{25}$ The Energy Policy Act of 2005 (EPA) commanded that the Secretary of the Interior should, by 2015, have approved non-hydropower renewable energy projects located on the public lands totaling at least 10,000 megawatts. ${ }^{26}$ This meant that the Bureau of Land Management (BLM) had to approve leases for that amount of renewable energy development on public land. This goal was met in October 2012 with the Secretary's approval of the Wyoming Wind Project Site. ${ }^{27}$

The American Reinvestment and Recovery Act of 2009 (ARRA), which encapsulated the stimulus package launched in response to the financial crisis of 2008, created numerous subsidies for wind, solar, and geothermal energy development. The act ultimately allowed the Department of Energy (DOE) to invest more than $\$ 31$ billion in clean energy projects across the nation. ${ }^{28}$ The act also provided tax incentives for renewable development, extending the Production Tax Credit for wind energy development through 2012, ${ }^{29}$ and implementing an option to elect a 30\% Investment Tax Credit or cash grant in lieu of the Production Tax Credit, and expanding a federal loan guarantee program managed by the DOE. ${ }^{30}$

Several states have aligned their policies with Congress'. Many have adopted renewable portfolio standards (RPSs), tools mandating that a certain percentage of retail electricity sold in the state must derive from renewable sources such as wind, solar, and biomass. ${ }^{31}$ Most states currently have either mandatory RPS programs or voluntary Renewable Portfolio Goals in place, ${ }^{32}$ with percentage targets varying considerably among them. ${ }^{33}$

The executive branch under President Barack Obama has actively supported the move toward large-scale renewable energy infrastructure development,

${ }^{25}$ Exec. Order No. 13,212, 66 Fed. Reg. 28,357 (May 18, 2001).

${ }^{26}$ Energy Policy Act of 2005, 42 U.S.C.A. \$S 15801-16538 (2014).

27 See Press Release, DePARTMENT OF INTERIOR (Oct. 9, 2012), http://www.doi.gov/news/pressreleases/Salazar-Authorizes-Landmark-Wyoming-Wind-

Project-Site-Reaches-Presidents-Goal-of-Authorizing-10000-Megawatts-of-Renewable-

Energy.cfm. Note, however, that approval of this much energy is very different from actual installation. The latter process is still in early stages of development.

${ }^{28}$ For an infographic of DOE ARRA funded projects, see Recovery Act, DEPARTMENT OF

ENERGY, http://www.energy.gov/recovery-act (last accessed Apr. 8, 2015).

292009 American Recovery and Reinvestment Act, Pub L. No. 111-5, 123 Stat. 115.

302008 Wind Technologies Market Report, U.S. DePARTMENT OF ENERGY $44-45$ (July 2009), available at http://www.nrel.gov/docs/fy09osti/46026.pdf.

31 See Renewable Portfolio Standards, NREL, http://www.nrel.gov/tech_deployment/state_local_governments/basics_portfolio_standar ds.html (last updated Sep. 8, 2014).

32 See Renewable Porffolio Standards, U.S. EPA, http://www.epa.gov/agstar/tools/funding/renewable.html (last accessed Apr. 28, 2015).

33 California, e.g., is much higher than most RPSs, and mandates 33\% renewable energy sourcing by 2020. CAL. PUB. UTIL. CODE \S 399.11-.20 (West 2015). 
particularly as a means of climate change mitigation. ${ }^{34}$ Notably, the administration has declared ambitious goals that dwarf the benchmark set by the 2005 EPA: to install 100 megawatts of renewable capacity across federally subsidized housing by 2020 , permit ten gigawatts of renewable projects on public lands by 2020 , deploy three gigawatts of renewable energy on military installations by 2025 , and double wind and solar electricity generation in the United States by $2025 .{ }^{35}$ Regarding federal permitting, the President has ordered all agencies to "take all steps . . . to execute Federal permitting and review processes with maximum efficiency and effectiveness." 36 The administration has also called for Congress to make permanent the renewable energy Tax Production Credit. ${ }^{37}$

\subsection{The Tension Between These Two Policies}

These efforts demonstrate the strong desire of both Congress and the Executive branch to reinforce the protection of threatened and endangered species while also quickly developing a robust national renewable energy infrastructure. Utility-scale renewable facilities often come at the cost of a large amount of incidental taking of endangered and threatened species populating the ecosystems where renewable energy resources are abundant. However, facilities of considerable size are integral to fulfilling both the federal renewable energy policy goal and the scientific recommendation to mitigate anthropogenic climate change via the rapid transition away from a fossil fuel-based energy system.

The tension between these two policies can be partially explained by chronological misalignment: the majority of America's larger infrastructural ambitions - the interstate highway system, the Intracoastal Waterway, the oil and gas pipeline system, the electric power grid, the airport and air traffic network, and the major river navigation and flood control systems - had been largely accomplished before the passage of the ESA in $1973 .{ }^{38}$ The federal government did not then contemplate the eventual necessity for renewable energy resources, nor the universal dangers that anthropogenic climate change would eventually pose. ${ }^{39}$ For this reason, the ESA's legal framework does not contemplate the accommodation of infrastructural endeavors on such a titanic scale. This oversight, combined with the

34 See, e.g., Climate Change, THe White House, https://www.whitehouse.gov/energy/climate-change (last accessed Apr. 25, 2015).

35 Securing American Energy, THE WhiTe HOUSE, https://www.whitehouse.gov/energy/securing-american-energy (last accessed Apr. 25, 2015).

36 Exec. Order No. 13,604 (2012), 77 Fed. Reg. 18,887 (Mar. 22, 2012).

37 THE White House, supra note 24.

${ }^{38}$ J.B. Ruhl, Harmonizing Commercial Wind Power And The Endangered Species Act Through Administrative Reform, 65 VAND. L. REV. 1769, 1774 (2012) (recounting the history of major infrastructural development in the United States).

${ }^{39}$ Kalyani Robbins, Responsible, Renewable, And Redesigned: How The Renewable Energy Movement Can Make Peace With The Endangered Species Act, 15 Minn. J. L. Sci. \& Tech. 555, 560-61 (2014) ("Climate change mitigation and adaptation were not foremost in the minds of the legislators who drafted the statute."); id. at 584 n.19 (noting that the author found nothing in legislative history of the ESA about climate change). 
specific harms that renewable facilities impose upon threatened and endangered species, ${ }^{40}$ produce a cumbersome and contradictory system that effectively undermines the ambitions of both policies.

\section{The Renewable Landscape}

While comprehensive technical details are beyond the scope of this paper, it is worth briefly describing renewable operations and the manners in which specific energy sources and facilities harm endangered and threatened species. Of primary concern to the federal policies described and this paper are wind and solar power, and their respective impacts on specific threatened or endangered species.

\subsection{Wind}

Wind energy is the most important energy source in the developing renewable infrastructure. It became the primary source of new U.S. energy in 2012, then producing 43 percent of new generating capacity. ${ }^{41}$ Wind energy produces no carbon pollution during operation, and, in the nation's windiest corridors, is limited only by transmission and storage. ${ }^{42}$ Generally, wind turbines require a higher initial capital investment than comparable fossil fuel energy generators, yet cost far less over their operating lives due to the absence of fuel costs. ${ }^{43}$ The ESA presents one of the few major hurdles to otherwise environmentally positive wind energy development.

\subsubsection{Technical Facts}

Wind turbines generally consist of three blades mounted to a tower; wind propels the blades, which power a generator located within the structure. The turbines operate most effectively when the blades are situated at altitudes higher than 100 feet. ${ }^{44}$ Control mechanisms within the turbines maintain maximum speeds of typically fifty-five miles per hour in order to avoid wind speed damage. ${ }^{45}$ Wind farms comprise numerous wind turbines, substations, and typically transport roads. ${ }^{46}$

\footnotetext{
40 See infra Part III.

41 See Brian Scheid, Wind Became Leading Source of New US Generating Capacity in 2012: DOE, PlatTS: MCGRAw Hill FinANCIAL (Aug. 6, 2013, 11:35 AM), http://www.platts.com/latest-news/electric-power/washington/wind-became-leadingsource-of-new-us-generating-21381199.

42 Robbins, supra note 29, at 569.

${ }^{43}$ Wind Energy Basics, DePARTMENT OF THE INTERIOR, http://windeis.anl.gov/guide/basics/ (last accessed Apr. 25, 2015).

${ }^{44}$ How a Wind Turbine Works, DePARTMENT OF ENERGy (June 20, 2014, 9:09 AM), http://energy.gov/articles/how-wind-turbine-works.

${ }^{45} \mathrm{Id}$.

46 See generally CONGRessional ReSEARCH SERVICE, Wind POWER IN THE UNITED STATES:

TECHNOLOGY, ECONOMIC, AND POLICY IsSUES (2008), available at http://fas.org/sgp/crs/misc/RL34546.pdf.
} 
Larger wind farms can span hundreds of square acres, and may contain hundreds of turbines.

\subsubsection{Threats to Wildlife}

Wind turbines threaten birds and bats through direct mortality risk. Wind farms operate best on landscapes where wind blows strongly and reliably; flying animals utilize these same windy corridors to efficiently propel themselves great distances. Inevitably, some of these animals collide with the turbines and are killed. ${ }^{47}$ Contrary to scientists' and developers' hopes that bats' echolocation abilities would deter them from wind turbines, these animals appear to be attracted to the turbines instead. ${ }^{48}$

Wind farms likewise pose implications for wildlife habitats. Wind farms require about 100 times as much land as coal and nuclear counterparts to produce a comparable amount of energy ${ }^{49}$ and thus interfere with roosts and nests located across the farm area. Large-scale construction of this nature fragments habitats, ${ }^{50}$ while the laying of transport roads and substations often requires grading and vegetation removal. ${ }^{51}$ These effects harm both aerial and land-based species.

Relevant to and illustrative of easily-triggered ESA prohibitions, wind farms are known for dangers they pose to the endangered Indiana bat, a species with a vast range of at least twenty midwestern and eastern states, ${ }^{52}$ much of its habitat overlaps significantly with current or planned wind farm locations. ${ }^{53}$ Because the ESA prohibits the taking of even individual members of an endangered or threatened species, the Indiana Bat poses tremendous difficulties and delays for the permitting of wind facilities.

${ }^{47}$ It is difficult to accurately estimate the number of birds and bats killed by turbines annually. Estimates generally range in the hundreds of thousands. See Rose Eveleth, How Many Birds to Wind Turbines Really Kill?, SMITHSONIAN.COM (Dec. 16, 2013), http://www.smithsonianmag.com/smart-news/how-many-birds-do-wind-turbines-reallykill-180948154/?no-ist.

${ }^{48}$ Brian Handwerk, Wind Turbines Give Bats the "Bends," Study Finds, NATiOnal GeOGRAPHiC News (Aug. 25, 2008), http://news.nationalgeographic.com/news/2008/08/080825-batbends.html.

${ }^{49}$ Alexandra B. Klass, Energy and Animals: A History of Conflict, 3 San Diego J. Climate \& Energy L. 159, 184 (2011-12).

${ }^{50}$ Defenders of Wildlife, MAKing RENEWAble Energy Wildlife Friendly 1, available at http://www.defenders.org/publication/making-renewable-energy-wildlifefriendly (last accessed Apr. 25, 2015).

51 Id. at 8 .

52 Indiana Bat (Myotis Sodalis), Endangered Species, U.S. FISH \& WILDLIFE SERVICE, http://www.fws.gov/midwest/endangered/mammals/inba/inbafctsht.html (last updated Apr. 14, 2015).

53 See Indiana Bat Fatalities at Wind Energy Facilities, U.S. FISH AND WILDLIFE SERVICE, http://www.fws.gov/midwest/wind/wildlifeimpacts/inbafatalities.html (last updated Dec. 2014). 


\subsubsection{Offshore Wind}

Wind farms may be sited in coastal waters to capture the significant wind resources abundant there. ${ }^{54}$ Offshore wind in state and federal waters blows more reliably than land-based, utility-scale energy source counterparts. ${ }^{55}$ The development of this resource is therefore a significant tactic in the strategy for fulfilling the country's renewable energy policy goals; for this reason, the Department of Energy has allocated over $\$ 227$ million since 2011 to facilitate it. ${ }^{56}$

The majority of offshore wind projects would be located quite far from land, in areas where the water is deep enough that traditional support structures, such as steel piles fixed to the seabed, cannot be reliably placed. ${ }^{57}$ Coastal turbines pose the same threats to nearby birds and bats as to land-based turbines; an additional danger is possible, as the impact from sounds generated from turbine operations and construction on local marine species is not yet understood. ${ }^{58}$

\subsection{Solar}

The sun's rays are a promising source of clean energy. Every hour, the sun projects more energy onto Earth than the human race uses in an entire year. ${ }^{59}$ Commercial solar energy facilities have proven to be fairly land-intensive. ${ }^{60}$ Unlike wind energy, solar energy typically cannot share land with agricultural systems. However, solar energy systems may be placed on degraded, otherwise unused land and brownfields. ${ }^{61}$ Solar energy is also a promising option for small-scale, distributed systems, such as rooftop solar panels. Overall, solar energy use has been surging for nearly twenty years, while capital investment costs have continued to fall. ${ }^{62}$

\footnotetext{
${ }^{54}$ Offshore Wind Research and Development, DEPARTMENT OF ENERGY, http://energy.gov/eere/wind/offshore-wind-research-and-development (last accessed Apr. 26, 2015).

55 Id.

${ }^{56} I d$.

${ }^{57} I d$.

58 New study calls for continuing need to assess impacts of offshore wind farms on marine species, CHESAPEAKE BIOLOGICAL LABORATORY (Oct. 16, 2014), http://www.umces.edu/cbl/release/2014/oct/13/assess-impacts-offshore-wind-farmsmarine-specie.

59 Solar Energy, National Geographic, http://environment.nationalgeographic.com/environment/global-warming/solar-powerprofile/ (last accessed Apr. 24, 2015).

60 See Environmental Impacts of Solar Power, UNION OF CONCERNED SCIENTISTS, http://www.ucsusa.org/clean_energy/our-energy-choices/renewableenergy/environmental-impacts-solar-power.html - .VULHSGbfhz0 (last updated Mar. 5, 2013).

${ }^{61} I d$.

62 See Solar Energy Prices See Double-digit Declines in 2013; Trend Expected to Continue, NREL (Oct. 20, 2014), http://www.nrel.gov/news/press/2014/15405.html.
} 


\subsubsection{Technical Facts}

Electricity-generating solar systems, known as "active" solar, ${ }^{63}$ fall into two categories: photovoltaic cells, also known as solar panels, and concentrated solar power (CSP). Solar panels permit sunlight to collide with semiconductor materials, which convert the light directly into electricity. ${ }^{64}$ However, solar panel efficiency is fairly low. CSP utilizes mirrors to direct sunlight to a fluid-filled focal point, which heats the fluid sufficiently to boil encapsulated water and power a traditional steamturbine generator. ${ }^{65} \mathrm{CSP}$ has only been proven to operate efficiently at a commercial scale, and is therefore always land-intensive. ${ }^{66}$

\subsubsection{Threats to Wildlife}

Both categories of active solar energy pose direct mortality risks to wildlife. CSP facilities tend to attract birds who confuse the mirrored panels for water bodies, and instinctively home in on them, unknowingly plunging themselves into superheated air streams. ${ }^{67}$ The siting of CSP and solar panel facilities in the nation's sunniest areas harms the habitat of the ground dwelling species such as the desert tortoise, listed as threatened under the ESA. ${ }^{68}$ These animals may be killed during construction and maintenance activities associated with solar facilities and transmission corridors. ${ }^{69}$

Like wind farms, solar facilities likewise threaten wildlife through habitat alteration. Facilities that may span thousands of acres are typically fenced off, cleared of vegetation, and graded, effectively segmenting desert corridors that local species would naturally traverse. ${ }^{70}$

\section{Legal Framework}

Based on the common harms that renewable facilities inflict on certain protected species, as described in Part III supra, it is clear that the majority of utilityscale facilities will need to comply with the legal framework for species conservation.

${ }^{63}$ The other category of solar energy is "passive," in which the sun heats stationary objects that retain the heat for discrete applications.

64 Solar Photovoltaic Technology Basics, NREL, http://www.nrel.gov/learning/re_photovoltaics.html (last updated Jul 25, 2014).

${ }^{65}$ Concentrating Solar Power (CSP) Technologies, SOLAR PEIS, http://solareis.anl.gov/guide/solar/csp/ (last accessed Apr. 25, 2014).

${ }^{66}$ CSP Technology Overview, DEPARTMENT OF ENERGY, http://solareis.anl.gov/documents/docs/NREL_CSP_1.pdf (last accessed Apr. 25, 2014). ${ }^{67}$ John Upton, Solar Farms Threaten Birds, SCIENTIFIC AMERICAN (Aug. 27, 2014), available at http://www.scientificamerican.com/article/solar-farms-threaten-birds/.

68 Mojave Desert Tortoise, U.S. FISH AND WILDLIFE SERVICE, http://www.fws.gov/nevada/desert_tortoise/dt/dt_threats.html (last updated Apr. 16, 2014).

${ }^{69} \mathrm{Id}$.

${ }^{70}$ Defenders of WildLIFE, supra note 40 , at 7. 
The ESA is of primary relevance to this framework, as is a federal district case applying it in the context of wind energy development.

\subsection{The Endangered Species Act}

The ESA creates a vast regulatory framework with which energy developers must comply in order to construct facilities that may adversely affect endangered or threatened species. Five discrete ESA elements characterize the conflict between renewable energy infrastructure development and the protection of endangered and threatened species: the listing provision, the take prohibition, the interagency consultation requirement, the incidental take provisions, and the citizen suit provisions.

\subsubsection{The Listing Provision}

Section 4 of the ESA authorizes the administrating agencies to designate by regulation, "on the basis of the best scientific and commercial data available," endangered and threatened species. ${ }^{71}$ These categorizations extend ESA protection to the listed species. Determinations involve a variety of scientific factors, ${ }^{72}$ and subsequently require the agency to designate "critical habitat" "73 in which the listed species dwell. ${ }^{74}$ The agencies must also develop "recovery plans" for the listed species, unless there is a determination that such a plan would not promote the conservation of the species. ${ }^{75}$

\subsubsection{The Take Provision}

Section 9 of the ESA prohibits the "take" " of listed species by all persons, including private and public entities subject to federal jurisdiction. A take includes "harm," which the Services have defined to include a significant habitat modification that leads to actual death or injury of protected species. ${ }^{77}$ There is no "de minimis" exception to this prohibition: a take of even one individual of a listed species violates the ESA.

Relevant here, both private renewable energy developers and federal action agencies that intend to lease or permit federal lands for development must comply with the take prohibition.

7116 U.S.C.A. $\$ 1533$ (2014).

${ }^{72} I d . \$ 1533(\mathrm{a})$.

73 "(i) the specific areas within the geographical area occupied by the species ... (I) essential to the conservation of the species and; (II) which may require special management considerations or protection; and (ii) specific areas outside the geographical area occupied by the species at the time it is listed in ..." Id. \$1532(5)(a).

${ }^{74} I d . \$ 1533(\mathrm{a})(3)$.

${ }^{75}$ Id. $\int 1533(\mathrm{f})(1)$.

76 "The term "take" means to harass, harm, pursue, hunt, shoot, wound, kill, trap, capture, or collect, or to attempt to engage in any such conduct." Id. \$1532(6).

77 Babbitt v. Sweet Home Chapter of Communities for a Great Oregon, 515 U.S. 687 (1995) (interpreting harm in this manner). 


\subsubsection{The Interagency Consultation Requirement}

In cases where federal agencies are acting in a manner that may cause harm to wildlife, or where private activities implicate a "federal nexus," extensive interagency consultation provisions, provided in Section 7 (a)(2), ${ }^{79}$ are activated. Ultimately, "action agencies"-the agency considering leasing or permitting activity on federal land- must use "best scientific and commercial data available," to "consult" with the relevant Service to ensure that actions they carry out, fund, or authorize do not "jeopardize" the continued existence of listed species or "adverse[ly] modif[y]" their critical habitat. ${ }^{80}$

Prior to the jeopardy determination, the action agency must take several determinative steps to ascertain whether such a determination is even necessary. ${ }^{81}$ Initially, the action agency must determine whether a listed species or critical habitat may be adversely affected by its action. If the agency determines that its action may not adversely affect either, then the ESA is not relevant insofar as the action is concerned; conversely, if there is a possibility of harm, the action agency must engage the relevant Service through informal consultation.

If informal consultation results in a determination that the action is likely to adversely affect a listed species, the action agency must then submit a request for formal consultation with the Service. Formal consultation may last up to ninety days, and requires the agencies to share information about the proposed project and species likely to be affected. ${ }^{82}$ At the conclusion of the ninety-day consultation period, the Service then has forty-five days to determine whether the proposed activity will jeopardize the continued existence of a listed species.

A jeopardy determination by the Service leaves the action agency with a limited number of options:

i. implement reasonable and prudent alternative provided by the Service, often obtained in consultation with the action agency; ${ }^{83}$

ii. modify the proposed project and consult again with the Service;

iii. decide not to undertake, fund, or authorize the project;

iv. disagree with the opinion and proceed; or

v. apply for an exemption. ${ }^{84}$

In the event of a non-jeopardy determination, the Service will inform the action agency whether any reasonable and prudent measures should be applied, and activate the incidental take procedure.

\footnotetext{
$78 \mathrm{~A}$ federal nexus is present when the project is being undertaken by a federal "action" agency, or when a private developer's project is significantly connected to a federal resource.

7916 U.S.C.A. \1536(a)(2) (2014).

${ }^{80} \mathrm{Id}$.

81 See $S 7$ Process Flow Chart, U.S. FISH AND WILDLIFE SERVICE, http://www.fws.gov/midwest/endangered/section 7/s7process/s7stepxstep.html (last updated Apr. 14, 2015).

8216 U.S.C.A. $\$ 1536(\mathrm{~b})(1)(\mathrm{A})(2014)$.

${ }^{83}$ Id. \$1536(a)(3)(A).

${ }^{84} \mathrm{Id}$. $\$ 1536(\mathrm{~g})$.
} 


\subsubsection{The Incidental Take Provisions: Statements and Permits}

Incidental take "results from, but is not the purpose of, carrying out an otherwise lawful activity." ${ }^{85}$ Action agencies that must obey the interagency consultation provisions, and private actors subject only to the take prohibition, may incidentally take listed species through respective approval processes before the Services.

\subsubsection{Incidental Take Statement}

Action agencies who have received a non-jeopardy determination following formal consultation with the Service will receive an incidental take statement, which includes the amount of anticipated take due to the action in question, reasonable and prudent measures to minimize the take, and terms and conditions that must be observed when implementing the minimizing measures. ${ }^{86}$

\subsubsection{Incidental Take Permit and Habitat Conservation Plan}

A private developer's application for an incidental take permit (ITP) activates a rigorous approval process under Section 10 of the ESA. The applicant must submit a habitat conservation plan (HCP) to the Service; this detailed document allows the applicant to comply with the ESA despite the likelihood of harm to a listed species though maximum possible mitigation of incidental takes. ${ }^{87}$ The HCP outlines: the impact which will likely result from such taking; what steps the applicant will take to minimize and mitigate such impacts, and the funding that will be available to implement such steps; what alternative actions to such taking the applicant considered and the reasons why such alternatives are not being utilized; and any such other measures that the Service may require. ${ }^{88}$

To approve the HCP, the Service must determine that:

i. the taking described in the plan will be incidental;

ii. the applicant will, to the maximum extent practicable, minimize and mitigate the impacts of the taking;

iii. the applicant will ensure that adequate funding for the plan will be provided;

iv. the taking will not appreciably reduce the likelihood of the survival and recovery of the species in the wild; and

v. any other measures the Service requires will be met. ${ }^{89}$

Upon approving the HCP, the Service will provide the private applicant with an ITP, which legally binds the applicant to the commitments in their HCP. ${ }^{90}$

\footnotetext{
85 Glossary, U.S. FiSH AND WILDlife SERVICE, http://www.fws.gov/midwest/endangered/glossary/index.html (last updated Apr. 14, 2015). 86 Id.

8716 U.S.C.A. \1539(a)(2)(A) (2014).

${ }^{88} \mathrm{Id}$.

${ }^{89}$ Id. $\$ 1539(\mathrm{a})(2)(\mathrm{B})$.
} 


\subsubsection{Citizen Suit Provision}

The ESA provides that virtually any person may commence litigation to enjoin violations of the act or to compel the Service to perform its nondiscretionary statutory duties. ${ }^{91}$ The vast majority of ESA enforcement occurs through the citizen suit mechanism. ${ }^{92}$

\subsection{Animal Welfare Institute v. Beech Ridge Energy, LLC}

In this case from the federal district court of Maryland, ${ }^{93}$ a plaintiff conservation group sued to enjoin the operation of a wind farm for failing to apply for and obtain an ITP despite the project's high likelihood of adversely impacting the Indiana Bat. The plaintiff's theory of ESA violation was that the defendant's construction and future operation of the wind project would impermissibly take members of the species. The court made three holdings relevant to the interaction between the ESA and wind development, and possibly renewable energy development more broadly:

i. The ESA's citizen-suit provision allows allegations of wholly-future violations of the statute, and does not require actual harm to have occurred; ${ }^{94}$

ii. in an action under the Section 9 prohibition on takes, a plaintiff must establish by a preponderance of the evidence, a relatively low standard of persuasion, that the challenged activity is reasonably certain to imminently harm, kill, or wound the listed species; ${ }^{95}$ and

iii. injunctive relief is appropriate where such takes are reasonably certain as shown by a preponderance of the evidence. ${ }^{96}$

This case appears to stand for two propositions: an expanded reading of the ESA citizen suit provision, allowing allegations that rely on a likelihood of whollyfuture takes based on a mere preponderance of the evidence; and that renewable energy developments, or at least wind projects, do not receive special treatment, consideration, or exemption under the take prohibition and ITP procedures of the ESA. ${ }^{97}$

On the other hand, the opinion affirms that the protection of endangered species and the development of renewable energy need not be in conflict; rather, the latter must follow the legal permitting procedures established pursuant to the former,

90 "The permit shall contain such terms and conditions as the Secretary deems necessary or appropriate to carry out the purposes of this paragraph. .." Id.

${ }_{91} I d . \$ 1540(\mathrm{~g})$.

${ }^{92}$ J.B. Ruhl, Harmonizing Distributed Energy And The Endangered Species Act, 4 San Diego J.

Climate \& Energy L. 121, 131 (2012-13) ("Outside the context of illegal trade and transport of protected species, virtually all ESA enforcement is through this citizen suit mechanism.").

93 Animal Welfare Institute v. Beech Ridge Energy LLC, 675 F.Supp.2d 540 (D.Md.,2009).

${ }^{94} I d$. at 561.

${ }^{95} \mathrm{Id}$. at 563.

${ }^{96} I d$. at 580.

${ }^{97}$ Ruhl, supra note 28, at 1786. 
an obligation which the defendants inexcusably neglected. ${ }^{98}$ Indeed, the injunctive relief commanded only partial cessation of turbine operations, and only under circumstances where Indiana Bats would be endangered; ${ }^{99}$ the injunction would be lifted upon the receipt of an appropriate ITP. ${ }^{100} \mathrm{Had}$ defendants applied for and received an ITP, they would have been shielded from Section 9 liability.

\section{Wiggle Room Under Existing Statutory Framework}

As described supra, renewable energy projects often disagree with certain listed species. Under Beech Ridge, mere likelihood of taking a single member of a listed species, based on a preponderance of evidence, is grounds for an injunction on operations that have not been granted an ITP. Near all applicants therefore need to comply with the incidental take procedure or risk greater susceptibility to legal battles and an injunction. The ESA thus hampers the development of renewable energy infrastructure temporally, through delayed project approval and completion; and financially, through increased costs of compliance and greater legal risk.

Developers, both with and without a federal nexus in their renewable project, must utilize all available "wiggle room" within the statutory framework to facilitate development and the obtainment of an ITP. Wiggle room is available to developers with or without a federal nexus, and includes the following categories: programmatic Section 7 consultation; Expanded HCPs under Section 10; ITP authority delegation; the "No Surprises" rule; exemptions from Section 7 requirements provided by the Endangered Species Committee; guidance; and listing and prosecutorial discretion.

\subsection{Programmatic Section 7 Consultation}

Federal agencies may attempt to facilitate the placement of multiple largescale utility projects across great, interstate swaths of federal land. Rather than fully consulting with Service pursuant to Section 7 for each individual project on that land, the agencies may instead engage in a programmatic consultation that largely satisfies the Section 7 requirement for future individual projects within the area. ${ }^{101}$ This programmatic consultation can be integrated into a broader programmatic

\footnotetext{
${ }^{98}$ Beech Ridge, 675 F.Supp.2d at 581 ("The two vital federal policies at issue in this case are not necessarily in conflict. Indeed, the tragedy of this case is that Defendants disregarded not only repeated advice from the FWS but also failed to take advantage of a specific mechanism, the ITP process, established by federal law to allow their project to proceed in harmony with the goal of avoidance of harm to endangered species.").

${ }^{99} I d$. at 580-81 ("The Court sees little need to preclude the completion of construction of those forty turbines already under construction, but ... any construction of additional turbines should not be commenced unless and until an ITP has been obtained.”).

${ }^{100} \mathrm{Id}$. at 581.

101 A subsequent, site-specific consultation under Section 7(a)(2) may be required. However, it would benefit from the programmatic consultation underlying the broader federal project, and would presumably be quicker and cheaper to accomplish than it would be without the programmatic consultation. See Endangered Species Act-Section 7 Compliance, BLM SOLAR ENERGY PROGRAM, http://blmsolar.anl.gov/program/laws/esa/ (last updated Aug. 14, 2013).
} 
environmental impact statement (PEIS) prepared by the agencies to fulfill the requirements of the National Environmental Policy Act of 1969 for federal approval of the same projects. ${ }^{102} \mathrm{~A}$ programmatic consultation's frontloaded costs would be preferable to full interagency consultations for each individual project in the area, which would delay infrastructural development and thereby disincentivize capital investment into the projects.

A major federal renewable energy projects conceived in light of the 2005 EPA's ambitious 10,000 megawatt goal exemplifies the programmatic Section 7 innovation.

In 2008, the Bureau of Land Management (BLM) and the DOE began the PEIS for Solar Energy Program for utility-scale solar energy ${ }^{103}$ development on BLM-administered federal lands in six southwestern states. ${ }^{104}$ The Program designated for analysis viable Solar Energy Zones (SEZs), but excluded other areas from consideration to maximize species conservation. In February 2012, the BLM began formal consultation with the FWS under Sections 7 (a)(1) and 7(a)(2). ${ }^{105}$ Consultation was completed in July of that year, and produced a programmatic biological opinion describing likelihood of harm to dozens of listed species in the assessed areas. ${ }^{106}$ Notably, the biological opinion determined that solar projects in SEZs are not likely to jeopardize the continued existence of these species or to destroy or adversely modify designated critical habitat. ${ }^{107}$ By laying consultation groundwork for future solar projects on the land in question, the Program allows permitting of individual solar projects in analyzed SEZs to proceed in a more efficient, standardized, and environmentally responsible manner than they otherwise would. $^{108}$

\subsection{Expanded Section 10 HCPs}

\subsubsection{General Conservation Plans}

Private developers whose projects do not involve a federal nexus may also take advantage of a large-scale approval mechanism to facilitate the granting of ITPs under Section 10. In 2007, FWS developed the General Conservation Plan (GCP) to streamline and reduce processes associated with HCP submission and ITP provision. ${ }^{109}$ The GCP approach allows the Service to develop a Section 10

\footnotetext{
102 National Environmental Policy Act, 42 U.S.C.A. \\ 4321-4347 (2014).

103 As applicable to the Solar Energy Program, utility-scale projects are those with capacities of 20 megawatts (MW) or greater that generate electricity that is delivered into the transmission grid. 
conservation plan suitable for the needs of a designated local area and the listed species therein, and to issue ITPs to landowners who demonstrate compliance with the GCP. Ultimately, a finalized GCP would make ITP issuance formulaic and expeditious, thus greatly facilitating abundant project development in the given area. ${ }^{110}$ Furthermore, the GCP process shifts the burden of developing a suitable conservation plan to the agency, thus freeing developers to apply resources on other facets of their projects. ${ }^{111}$

\subsubsection{Regional Habitat Conservation Plans}

A grander, related mechanism is the Regional Habitat Conservation Plan (RHCP), ${ }^{112}$ which expands the HCP process over a broad region and unifies the ITP processes for all listed species within that region. ${ }^{113}$ Individual projects within that region could utilize the RHCP and obviate further permitting processes. ${ }^{114}$ Interested private and public parties along with the FWS typically prepare RHCPs; benefited parties thus share a regulatory burden that would otherwise greatly delay private project development.

Because the RHCP mechanism can cover vast geographical corridors and account for multiple listed species within them, it can greatly expedite utility-scale commercial wind and solar development. ${ }^{115}$ Currently, three major renewable energy RHCPs are in various stages of completion:

i. The Great Plains Wind Energy HCP: Covering four listed species ${ }^{116}$ in a 200 mile-wide, 1500 mile-long corridor-approximately 268 million acres-through the country's center, this plan intends to "comprehensively address potential wind energy development impacts to listed or sensitive species, allowing for more effective conservation and a more efficient permit process." "117 The Plan's primary developer is a coalition of fifteen wind energy companies, ${ }^{118}$ working in concert with two FWS regional offices and the wildlife agencies of the nine affected states ${ }^{119}$ in the Plan area. Plan completion is scheduled for $2015 .{ }^{120}$

\footnotetext{
${ }^{110} \mathrm{Id}$.

$111 \mathrm{Id}$. at 2

${ }^{112}$ FWS developed these in 1990s for centers of urban land development. Ruhl, supra note 28, at 1783 .

$113 \mathrm{Id}$.

${ }_{114} \mathrm{Id}$.

$115 \mathrm{Id}$.

116 The Whooping Crane, the Piping Plover, the Lesser Prairie-Chicken, and the Interior Least Tern.

117 Home, WEWAG (2013), http://www.greatplainswindhcp.org/index-2.html.

118 Acciona-North America, Allete, BP Wind Energy, Competitive Power Ventures Inc., Duke Energy Renewables, EDP Renewables North America, Element Power, EDF-

Renewable Energy, Iberdrola Renewables, Infinity Wind Power, MAP Royalty, NextEra Energy Resources, RES Americas, Trade Wind Energy, and Wind Capital Group. ${ }^{119}$ North Dakota, South Dakota, Montana, Colorado, Nebraska, Kansas, New Mexico, Oklahoma, and Texas.

120 Schedule, WEWAG (2013), http://www.greatplainswindhcp.org/schedule.html.
} 
ii. The Midwest Habitat Conservation Plan: This Plan covers twentyseven million acres and thirty federally listed species. ${ }^{121}$ Its developers comprise a coalition of eight affected midwestern states, ${ }^{122}$ the FWS, and representatives of the wind industry.

iii. The Desert Renewable Energy Conservation Plan: focused entirely in California and encompassing multiple renewable energy sources, ${ }^{123}$ this Plan covers 22.5 million federal and non-federal acres. The Plan also intends to facilitate the state's RPS and other renewable energy ambitions. ${ }^{124}$ Overseeing it is a coalition of federal and state agencies, local governments, environmental advocates, and renewable energy industry representatives. ${ }^{125}$ Plan completion is scheduled for $2015 .{ }^{126}$

In addition to offshore wind development, the regions covered by these plans could, according to the Department of Energy, provide renewable energy sufficient to meet the electrical needs of the country "several times over." 127 Promisingly, the development of these RHCPs appear to demonstrate a broad movement toward preferred use of the mechanism; ${ }^{128}$ despite the frontloaded financial requirements and long timeframes required for completion, ${ }^{129}$ these tools will considerably expedite the renewable infrastructure development in areas where the energy is most abundant.

121 Strategic Mitigation for Wind Energy In the Midwest, THE CONSERVATION Fund, http://www.conservationfund.org/projects/wind-energy-in-the-midwest (last accessed Apr. $28,2015)$.

122 Indiana, Ohio, Michigan, Iowa, Missouri, Illinois, Wisconsin, and Minnesota. 123 "The DRECP will encompass development of solar thermal, utility-scale solar photovoltaic (PV), wind, and other forms of renewable energy and associated infrastructure such as electric transmission lines necessary for renewable energy development within the Mojave and Colorado desert regions of California." The Desert Renewable Energy Conservation Plan (DRECP), RENEWABLE ENERGY ACTION TEAM, http://www.drecp.org/whatisdrecp/ (last accessed Apr. 28, 2015).

124 "Streamlined permitting of renewable energy projects is critical to meeting the Renewable Portfolio Standard (RPS) established by state law. In addition to the RPS, Senate Bill 2X (Simitian), signed into law by Governor Edmund Brown, Jr. on April 12, 2011, as Public Resources Code $\$ 25740$, requires California to meet the 33 percent renewable energy portfolio standard by 2020." Id.

125 The U.S. Bureau of Land Management (BLM), U.S. Fish and Wildlife Service (USFWS), California Energy Commission (CEC), and California Department of Fish and Wildlife (CDFW) several other state and federal agencies that manage lands or programs in the desert or that manage or regulate renewable energy development and transmission. Local governments, environmental organizations, renewable energy developers, and utilities are also involved. The Frequently Asked Questions, RENEWABLE ENERGy ACTION TEAM, http://www.drecp.org/whatisdrecp/faq.html (last accessed Apr. 28, 2015).

126 Schedule, RENEWABLE ENERGy ACTION TEAM, http://www.drecp.org/whatisdrecp/schedule.html (last accessed Apr. 28, 2015).

127 Ruhl, supra note 28, at 1784 (citing the Department of Energy).

128 Robbins, supra note 29, at 574 (arguing that there is a broad movement toward creating RHCPs to "reduce both risk and delay").

${ }^{129}$ Ruhl, supra note 28, at 1783-84 (noting that large RHCPs will take years to complete). 


\subsubsection{ITP Authority Delegation}

Developers who choose to comply with the criteria of a GCP or an RHCP, and thus avoid submitting their own HCP, must still apply for an ITP to receive insulation from take liability. ${ }^{130}$ To facilitate this process, the Service may delegate ITP approval authority to local governments situated within the expanded plan territory so long as they sign onto the plan's criteria. The local government can then issue ITPs to renewable energy developers sited inside their jurisdiction. ${ }^{131}$ This approach shifts significant administrative burden away from the Service and onto local governments; doing so not only expedites ITP issuance and facilitates project development, but also promotes tighter interaction between the permit issuer and developer.

\subsubsection{The "No Surprises" Rule}

The "no surprises" rule ${ }^{132}$ is an ITP policy under which the Service cannot be held accountable for unforeseen circumstances that adversely affect listed species once the developer has been issued an ITP for that species. A situation of this nature could arise, for example, where a developer's mitigation plan, contained in their HCP, has been approved by the Service and ultimately proves insufficient. The rule effectively clarifies conservation costs for the developer by hemming the risk that they will increase, and redistributes liability over the project's lifespan to the Service.

\subsubsection{Exemptions}

Perhaps the most infamous abrogating provision in the ESA regards a federal-nexus developer's ability to obtain from the Endangered Species Committee an exemption from the Section 7(a)(2) prohibition on jeopardizing a listed species in situations where a listed there exists no reasonable alternative to the action. ${ }^{133} \mathrm{In}$ effect, exemption from this requirement allows a listed species' continued existence to be jeopardized. In other words, the Committee can allow a species' extinction.

The Committee comprises seven members, each possessing a single vote on the exemption determination: the head officials of six relevant federal agencies, ${ }^{134}$ and a representative from the state in which the species' existence is to be determined. Five votes in favor of an exemption are sufficient. These votes represent the committee's opinion that the project under consideration satisfies the following criteria: ${ }^{135}$

\footnotetext{
130 See ReNEWABLE ENERgy ACTION TEAm, supra note 115 (describing the ITP delegation in that plan).

${ }^{131} I d$.

13263 Fed. Reg. 8,859 (Fed. 23, 1998).

13316 U.S.C.A. $\int 1536$ (g) (2014).

134 Agriculture, Army, Interior, Council on Environmental Quality, Environmental

Protection Agency, and National Oceanic and Atmospheric Administration. Id. at $₫ 1536(\mathrm{e})$.

${ }^{135} I d$. at $\$ 1536(\mathrm{~h})$.
} 
i. there are no reasonable and prudent alternatives to the agency action;

ii. the benefits of such action clearly outweigh the benefits of alternative courses of action consistent with conserving the species or its critical habitat, and such action is in the public interest;

iii. the action is of regional or national significance; and

iv. neither the Federal agency concerned nor the exemption applicant made any irreversible or irretrievable commitment of resources ... ${ }^{136}$

Additionally, the committee must establish "reasonable mitigation and enhancement measures . . . to minimize the adverse effects of the agency action upon the [species]." 137

The Committee's ability to permit extinction initially seems to make exemption a viable means for renewable energy projects with a federal nexus to proceed expeditiously; given the great abundance of solar and wind energy sources available on federal lands, the exemption option should expedite the energy infrastructure's transformation. However, exemptions are limited in application due to the narrow circumstances under which they must be applied: only federal nexus actions that jeopardize the continued existence of the species, and have no reasonable and prudent alternatives of application, are under consideration for an exemption. It is difficult to imagine a renewable energy project involving a federal nexus that both jeopardizes a species' existence and has no alternatives. This structural limitation explains the infrequency of Committee meetings. ${ }^{138}$

\subsubsection{Guidance}

The Service may employ non-binding, communicative guidance to facilitate development of renewable energy projects in as efficacious a manner as possible, while ensuring compliance with ESA prohibitions. Such guidance could outline the most efficient procedures for a developer to follow in order to quickly gain project approval and reduce the likelihood of legal liability during operation.

The FWS applied this method by crafting its Land-Based Wind Energy Guidelines in March 2012, based on the recommendations of the Wind Turbine Guidelines Advisory that the agency had commissioned in five years earlier. ${ }^{139}$ The Guidelines promote a five-tiered methodology to project monitoring and communication between the wind project developer and the FWS that is intended to "form the best practical approach for conservation of species of concern.","

Although the guidelines intend to promote compliance with the ESA, in the cheapest and most efficient manner possible, adherence to them is voluntary and

$136 I d$. at $\int 1536(\mathrm{~h})(1)(\mathrm{A})(\mathrm{i})-(\mathrm{iv})$.

137 Id. at $\$ 1536(\mathrm{~h})(1)(\mathrm{B})$.

138 As of 2008 , the committee had only met three times.

139 Ruhl, supra note 28, at 1778-79; Land-Based Wind Energy Guidelines, U.S. Fish and Wildlife Service (Mar. 23, 2012), available at http://www.fws.gov/windenergy/docs/WEG_final.pdf. ${ }^{140} \mathrm{Id}$. at 1 . The tiers are: 1 . Preliminary site evaluation (landscape-scale screening of possible project sites); 2. Site characterization (broad characterization of one or more potential project sites); 3. Field studies to document site wildlife and habitat and predict project impacts; 4. Post-construction studies to estimate impacts; 5. Other postconstruction studies and research. 
does not "relieve any individual, company, or agency of the responsibility to comply with laws and regulations." 141 However, a documented history of a developer's efforts to maintain communication with the FWS and adhere to the guidelines may benefit them in the event of violation. ${ }^{142}$

Despite the obvious shortcomings of voluntary guidelines, guided communication between project developers and Services would benefit the move toward a renewable energy infrastructure by both facilitating individual projects, and developing a standardized, reusable development procedure for situated projects.

\subsubsection{Listing and Prosecutorial Discretion}

The Service, upon determining that creation of renewable infrastructure is necessary to the grander well-being of endangered and threatened species, could simply choose not to list species or prosecute violations of the ESA. However, the majority of ESA enforcement occurs through the act's citizen suit provision, through which any person can either commence litigation to enjoin ESA violations, or compel the Service to perform its nondiscretionary statutory duties. ${ }^{143}$

\section{Potential Solutions and Improvements}

Services and action agencies clearly have some discretion within the current ESA statutory framework to facilitate the development of a renewable energy infrastructure. However, these options are limited. Major amendments to the ESA that explicitly provide renewable energy projects with special leeway would be the most effective means of expediting infrastructural transformation, but it is also unlikely given the current legislative climate. This Part suggests additional means of facilitating renewable development under the current statutory framework.

\subsection{Land Ranking within RHCPs}

RHCPs already represent a substantial innovation in the large-scale incidental take permitting and expediting ESA compliance; these collaborations allow insight as to siting in locations within the vast area where there is a lower likelihood of taking a listed species. Services could enhance RHCPs by "rank" areas within the considered region at which a taking may occur. ${ }^{144}$ Rather than simply advise which parts of the region would be unsuitable for development, the agency might rate locations according to the likelihood of taking, and make development more "expensive" as the likelihood and number of listed species affected by the project increases. ${ }^{145}$ Under this approach, development on areas of low concern would not change, while

\footnotetext{
${ }^{141} I d$. at vii.

142 "However, if a violation occurs the Service will consider a developer's documented efforts to communicate with the Service and adhere to the Guidelines." Id.

${ }^{143}$ Ruhl, supra note 82, at 130-31.

${ }^{144}$ Robbins, supra note 29, at 575 (suggesting that Services "rank" land within RHCPs).

${ }^{145} \mathrm{Id}$.
} 
development on regions of moderate concern where listed species transit more frequently would obligate the developer to adopt more stringent commitments. ${ }^{146}$ These commitments might be embodied in technological or mitigation requirements, such as the usage of safer wind turbines or solar panels designed to ward off aerial animals. Molding RHCPs in this flexible fashion would benefit both clashing policies: it will open up a greater amount of land to the development of renewable energy sources, attach development incentives to the potential of threatened species, and ultimately preserve more listed species.

\subsection{Triggering an Exemption from Section 7 Interagency Consultation}

As described supra, it is difficult to obtain an exemption from the Section 7 (a)(2) non-jeopardy requirement because only federal-nexus projects that jeopardize a listed species' existence and have no reasonable alternatives can come under the Endangered Species Committee's consideration. Even then, the Committee would need to determine that allowing the extinction outweighs preserving the species, benefits the public interest, and is of national importance. Only rarely would an exemption applicant-likely a federal agency rather than a private developer-craft a project of this magnitude. It is perhaps ironic that an exemption could allow an action agency to more easily implement a project significant enough to threaten a listed species' existence than a safer, more conservative project with numerous alternatives.

Based on the policy supporting the development of a renewable energy infrastructure, federal agencies could align their positions such that the granting of an exemption is more likely. Initially, an action agency, such as the BLM, could design a renewable energy project, like the Solar Energy Program described supra, of magnitude sufficient to jeopardize the continued existence of a listed species. Following programmatic Section 7 consultation, the Service could maintain the position that the project meets threshold requirements for exemption consideration. ${ }^{147}$ The Committee would then need to determine if the project satisfies the criteria for an exemption. By recognizing that catastrophic climate change would very likely wipe out listed species, the Committee could feasibly determine that a large-scale renewable energy project: has no reasonable and prudent alternatives; offers benefits that outweigh conserving species; is in the public interest, and is of national-indeed, global-significance. ${ }^{148}$

\subsection{Enhanced Service Guidance}

Even if an alignment of action agency and Committee positions with the renewable energy policy yielded an exemption, however, the result would suffer from

\footnotetext{
${ }^{146} I d$

14716 U.S.C.A. \$S $1536(\mathrm{~g})(1)-(3)(2014)$.

${ }^{148} I d . \$ 1536(\mathrm{~h})(1)(\mathrm{A})$.
} 
drawbacks. First, the decision would be susceptible to judicial review. ${ }^{149}$ Second, an exemption as to one jeopardized, listed species would not necessarily aid the action agency in regards to ESA requirements concerning other listed species that would be affected in a less dramatic fashion.

Services could more regularly employ informal, non-binding guidance mechanisms to facilitate renewable energy development. These agencies could create a set of universally applicable guidelines analogous to those that the FWS formulated for utility-scale wind power. Perhaps the five-tiered approach described therein could be generalized for application to development of all major renewable energy schemes, such as utility-scale solar, offshore wind, and distributed wind and solar. ${ }^{150}$ Following a developer's demonstration of compliance with the guidelines, the Service could issue "no take" letters indicating there is no risk of taking a listed species. ${ }^{151}$ Such letters would indicate the agency's concurrence that the project in question was designed to avoid taking listed species, though they would not necessarily authorize a take were one to occur. Regardless, the letter would help the developer to secure financing and local and state approvals for the project. ${ }^{152}$

\subsection{ESA Amendments}

Amending the ESA to accommodate renewable energy development would be the most reliable way of ensuring that the act does not significantly inhibit the development of this new and necessary infrastructure. Given the current political and legislative climate, amendment seems unlikely. However, were political realities set aside, and ESA amendment possible, the following measures would prove beneficial.

\subsubsection{The Provision of a "Green Pass" for Renewable Energy Projects}

The foregoing demonstrates that there is no "green pass" under either the spirit or letter of the ESA that would permit renewable energy projects to possess a blanket exemption from the take prohibition. Implementing provisions whereby the Service could determine if a project developer satisfies criteria for such a pass, and then grant one, would preclude many of the difficulties expounded in this paper. These criteria would need to be explicit and clearly define what constitutes a green pass project. ${ }^{153}$ Rather than pour time and money into assuring that siting, agency consultations, and mitigation plans accord with the ESA, developers could initially focus on formulating projects sufficiently deserving of a green pass and develop

149 See, e.g., Portland Audubon Soc. v. Endangered Species Committee, 984 F.2d 1534 (9th Cir.1993) (holding that the "whole record" of the Committee's deliberation had to be made available for judicial review).

150 See Ruhl, supra note 82, at 134 (suggesting the use of guidance in this fashion).

${ }^{151} \mathrm{Id}$.

152 Id. at 138 n.52 (describing the author's experience with "no take" letters).

153 Vagueness would undermine this provision by exposing it to misappropriation by private developers for whom it was not intended, e.g., hydraulic fracturing companies that attempt to claim they provide "clean energy." 
securely thereafter. This innovation would likely open the statutory floodgates to widespread, low-cost renewable energy development immune to liability under the ESA.

\subsubsection{Discourage Citizen Suits for Renewable Projects}

Amending the ESA to prohibit citizen suits against renewable energy projects would effectively protect such projects from ESA enforcement. This amendment would retain the Service's prosecutorial discretion, and allow litigation against renewable energy developers to proceed at a pace and in a direction determined by the executive branch, rather than by the judiciary. As with a green pass amendment, the statute would need to state explicitly exactly what constitutes a renewable energy project deserving of insulation from a suit. Ideally, the developer would apply for and receive that designation at the initial stages of application.

\section{Conclusion}

The ESA clearly inhibits the country's ability to achieve its goal of implementing a renewable energy infrastructure and escaping the bondage of fossil fuels. While the Services and project developers have made strides towards that infrastructure in recent years, the nation's long-standing focus on protection of listed species, embodied by an act that prohibits takes across the board, continues to hamper progress towards this vital ambition.

Federal agencies have been creative in their means of expediting renewable energy project development, notwithstanding the likelihood that such projects will regularly take endangered and threatened species. Large-scale innovations like programmatic Section 7 consultations and RHCPs are promising, but they, along with every other measure so far employed, are not bringing the nation a new energy landscape with necessary speed.

Stringent, bright-line amendments to the ESA would provide a highly effective means of boosting the renewable transition; but legislative reform of this nature is likely not practical at present. Administrative efforts and technological progress that push projects through the ESA more expeditiously will hopefully suffice until the day for reform comes-if it ever comes. 